einstein

Official Publication of the Instituto Israelita

de Ensino e Pesquisa Albert Einstein

ISSN: 1679-4508 | e-ISSN: 2317-6385

\title{
Structured thoracic computed tomography report for COVID-19 pandemic
}

\author{
Relatório estruturado de tomografia computadorizada de \\ tórax para a pandemia do COVID-19
}

Hamilton Shoji', Eduardo Kaiser Ururahy Nunes Fonseca', Gustavo Borges da Silva Teles', Rodrigo Bastos Duarte Passos' ${ }^{1}$ Elaine Yanata', Murilo Marques Almeida Silva', Marcelo Buarque de Gusmão Funari', Roberto Sasdelli Neto', Walther Yoshiharu Ishikawa', Rodrigo Caruso Chate', Gilberto Szarf ${ }^{1}$

${ }^{1}$ Hospital Israelita Albert Einstein, São Paulo, SP, Brazil.

DOI: 10.31744/einstein_journal/2020ED5720

By the end of 2019, a novel coronavirus (severe acute respiratory syndrome coronavirus 2 or SARS-CoV-2) was identified as the etiologic agent of an outbreak of pneumonia in the city of Wuhan, province of Hubei, in China. The virus had a rapid dissemination, with person-to-person transmission and cases soon identified throughout the world. The disease was called COVID-19 (coronavirus disease 2019), with several new outbreaks related to community transmission. It is now classified as pandemic. ${ }^{(1-4)}$

We have observed an increase in requests of chest computed tomography (CT) since the first records of cases in Brazil; therefore, in a near future, the current installed capacity of the system to analyze and produce the CT reports may be exceeded. It is crucial to highlight that the definite diagnosis of COVID-19 is made by real-time polymerase chain reaction (RT-PCR), and a normal (negative) chest CT does not rule out diagnosis. However, currently, the RT-PCR result has taken longer than CT reports to be available, so CT has taken an important role in a comprehensive assessment of patients, for demonstrating high sensitivity (although low specificity), to detect the most frequent pulmonary findings of the disease.

In this high demand urgency context to provide results, it is advisable that the content of the radiological report be very objective and as clear as possible for the requesting physicians from the emergency department. The most relevant pieces of information to be conveyed are presence (or not) of pulmonary involvement, if the findings are compatible with infectious process, and, in positive cases, if the changes are suggestive of viral etiology, particularly COVID-19, even if there is overlapping of findings with other infectious diseases (including other viruses). We also included an approximate estimate of extent of pulmonary involvement by the disease (visual analysis), which has been considered useful by them in management of patients, together with other clinical data and physical examination. In our Institution, involvement of $>50 \%$ of parenchyma ${ }^{(5)}$ has been used as an additional criterion to decide for hospitalization.

In a structured report, we initially describe if there are pulmonary changes or not, and if they are suggestive of a pulmonary infectious process. In case 
of alterations, if the features are in accordance or not with the more typical pattern described in COVID-19: including ground-glass opacities, sometimes with superimposed interlobular septal thickening (crazy paving), consolidations and reversed halo, presenting a bilateral multilobar distribution, predominantly peripheral, with mild predilection for the posterior regions and lower lobes. ${ }^{(6-10)}$ In these cases, we have highlighted in our reports that "the possibility of COVID-19 should be considered in the differential diagnoses", and also included the estimated extent of parenchyma involvement (greater or lesser than $50 \%)^{(5)}$ Figure 1 shows a case with typical imaging findings of COVID-19 and the model of provided report.

In patients with tomographic findings more suggestive of other type of infection which obviously must not be neglected amidst the pandemic, we have described the changes and concluded as follows: "Such findings are compatible with pulmonary infectious process, and its characteristics are not typically observed in cases of pulmonary involvement by COVID-19; other etiologic agents should be initially considered in the differential diagnosis." As examples of changes described in the literature as uncommon in cases of COVID-19, which increase the probability of infection by other agents, we underline numerous centrilobular micronodules with tree-in-bud pattern, relatively welldefined solid nodules, cavities, predominant central parenchyma involvement, mainly affecting the airways. ${ }^{(6-9)}$ Figure 2 displays an example of one of those cases and its respective report, with final diagnosis of tuberculosis after complete investigation.

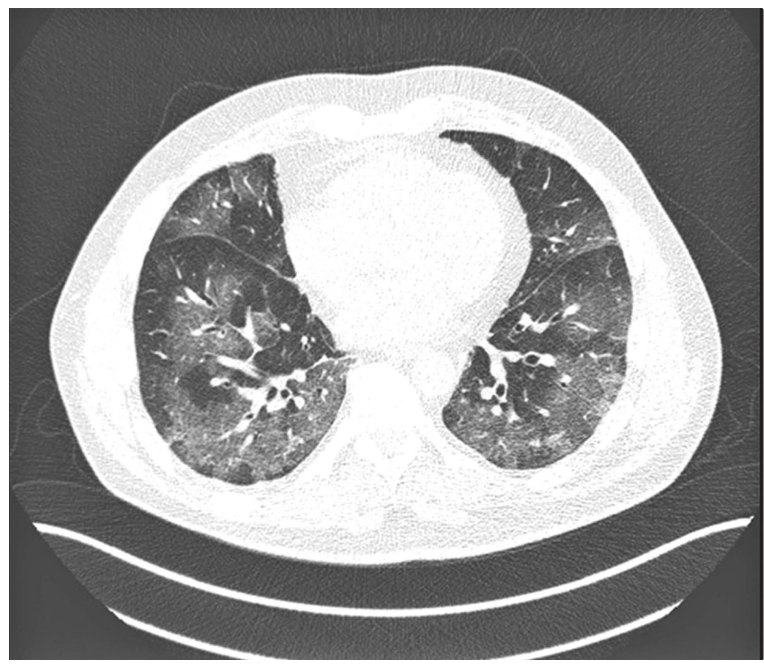

HIGH-RESOLUTION COMPUTED TOMOGRAPHY OF THE LUNGS

TECHNIQUE:

Multislice helical CT, without intravenous contrast.

INDICATION:

Assessment of pulmonary infectious disease (investigation of pulmonary involvement by COVID-19)

ANALYSIS:

Multiple ground-glass pulmonary opacities, sometimes associated to interlobular septal thickening and fine reticulation, presenting bilateral multifocal distribution, mostly periphera and posterior, more extensively in lower lobes. Although not specific, such findings are consistent with viral pneumonia, and the possibility of COVID-19 should be included in the differential diagnoses. The estimated extent of pulmonary involvement in the tomography is greater than $50 \%$ (visual analysis).

\section{Other findings:}

Absence of pleural effusion.

Remaining lung parenchyma with no significant abnormalities.

No mediastinal lymphadenopathy.

Vascular mediastinal structures with no abnormalities.

Other thoracic structures with no clinically relevant findings.

Figure 1. Computed tomography image of a confirmed case of COVID-19 with typical findings and its respective report
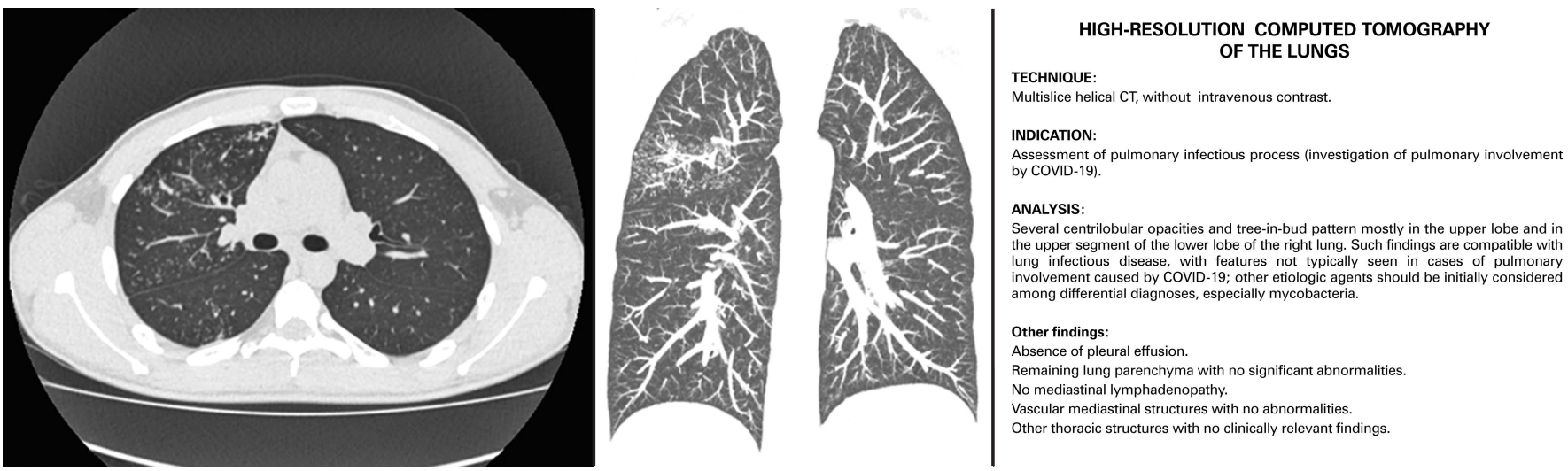

Figure 2. Computed tomography images of a case with initial clinical suspicion of COVID-19 and its respective report, with tomographic findings suggestive of infectious process, but with characteristics that are not usual in COVID-19. After performing ancillary investigations, the diagnosis was pulmonary tuberculosis 
In the subgroup of patients with no tomographic evidence of pulmonary infectious process, we clearly and explicitly report the following phrase: "Absence of focal pulmonary opacities suggestive of active parenchymal infectious process."

Next, other additional relevant findings are briefly included, emphasizing the presence or not of lymph node enlargement, pleural effusion, as well as pulmonary nodules, emphysema, chronic interstitial disease, aneurysms and marked atheromatous disease.

Developing structured reports in radiology, primarily those oriented to certain diseases, provides several benefits, including clarity in conveying information to requesting physicians and use of a common terminology, enabling all those involved to be familiar with specific terms used for each disease. Moreover, this later enables collecting data for epidemiological purposes, quality control and research. ${ }^{(11,12)}$ Other advantages comprise increased radiologist productivy with less burden. ${ }^{(12)}$

Implementing a structured report should be beneficial, particularly in the current scenario of COVID-19 pandemic, for increasing productivity of radiologists and enabling better understanding of the requesting physicians, with a potential positive impact in management of patients. ${ }^{(13)}$

\section{AUTHORS' INFORMATION}

Shoji H: http://orcid.org/0000-0002-3701-4647

Fonseca EK: http://orcid.org/0000-0002-0233-0041

Teles GB: http://orcid.org/0000-0002-5405-5029

Passos RB: http://orcid.org/0000-0003-2428-2287

Yanata E: http://orcid.org/0000-0001-7493-2976

Silva MM: http://orcid.org/0000-0003-3748-5649

Funari MB: http://orcid.org/0000-0002-6369-3612

Sasdelli Neto R: http://orcid.org/0000-0003-0337-9469

Ishikawa WY: http://orcid.org/0000-0002-5909-5126

Chate RC: http://orcid.org/0000-0002-4193-7647

Szarf G: http://orcid.org/0000-0002-1941-7899

\section{REFERENCES}

1. National Health Commission of the People's Republic of China. New coronavirus cases rise to 571 in Chinese mainland [Internet]. China: 2020 [cited 2020 Mar 16]. Available from: http://en.nhc.gov.cn/2020-01/23/c_76004.htm

2. World Health Organization (WHO). Novel Coronavirus - Republic of Korea (exChina) [Internet]. Geneva: WHO; 2020 [cited 2020 Mar 16]. Available from: https://www.who.int/csr/don/21-january-2020-novel-coronavirus-republic-ofkorea-ex-china/en/

3. European Centre for Disease Prevention and Control [ECDC]. Geographical distribution of 2019-nCov cases. Situation update worldwide, as of 27 March 2020 [Internet]. ECDC; 2020 [cited 2020 Mar 16]. Available from: https:// www.ecdc.europa.eu/en/geographical-distribution-2019-ncov-cases

4. Centers for Disease Control and Prevention [CDC]. Coronavirus Disease 2019 (COVID-19). Cases in U.S [Internet]. USA: CDC; 2020 [cited 2020 Mar 16]. Available from: https://www.cdc.gov/coronavirus/2019-ncov/cases-in-us.html

5. Zhao W, Zhong Z, Xie X, Yu Q, Liu J. Relation between chest CT findings and clinical conditions of coronavirus disease (COVID-19) pneumonia: a multicenter study. AJR Am J Roentgenol. 2020 Mar 3:1-6. doi: 10.2214/ AJR.20.22976

6. Bai HX, Hsieh B, Xiong Z, Halsey K, Choi WC, Tran TM, et al. Performance of radiologists in differentiating COVID-19 from viral pneumonia on chest CT. Radiology. 2020 Mar 10:200823. doi.org/10.1148/radiol.2020200823

7. Ng MY, Lee EY, Yang J, Yang F, Li X, Wang H, et al. Imaging profile of the covid-19 infection: radiologic findings and literature review. Radiol Cardiothorac Imaging. 2020;2(1):e200034.

8. Chung M, Bernheim A, Mei X, Zhang N, Huang M, Zeng X, et al. CT Imaging Features of 2019 Novel coronavirus (2019-nCoV). Radiology. 2020;295(1):202-7.

9. Kong W, Agarwal PP. Chest Imaging Appearance of COVID-19 Infection. Radiol Cardiothorac Imaging. 2020;2(1):e200028.

10. Rodriguez-Morales AJ, Cardona-Ospina JA, Gutiérrez-Ocampo E, VillamizarPeña R, Holguin-Rivera Y, Escalera-Antezana JP, Alvarado-Arnez LE, BonillaAldana DK, Franco-Paredes C, Henao-Martinez AF, Paniz-Mondolfi A, LagosGrisales GJ, Ramírez-Vallejo E, Suárez JÁ, Zambrano LI, Villamil-Gómez WE, Balbin-Ramon GJ, Rabaan AA, Harapan H, Dhama K, Nishiura H, Kataoka H, Ahmad T, Sah R; Latin American Network of Coronavirus Disease 2019-COVID-19 Research (LANCOVID-19). Electronic address: https: // www.lancovid.org. Clinical, laboratory and imaging features of COVID-19: a systematic review and meta-analysis. Travel Med Infect Dis. 2020 Mar 13:101623. Review. doi: 10.1016/j.tmaid.2020.101623.

11. Noumeir R. Benefits of the DICOM structured report. J Digit Imaging. 2006;19(4):295-306

12. Ganeshan D, Duong PT, Probyn L, Lenchik L, McArthur TA, Retrouvey M, et al. Structured Reporting in Radiology. Acad Radiol. 2018;25(1):66-73. Review.

13. Simpson S, Kay FU, Abbara S, Bhalla S, Chung JH, Chung M, Henry TS, et al. Radiological Society of North America Expert Consensus Statement on Reporting Chest CT Findings Related to COVID-19. Endorsed by the Society of Thoracic Radiology, the American College of Radiology, and RSNA. Radiology: Cardiothoracic Imaging. 2020;2:2:1-24. https://doi.org/10.1148/ryct.2020200152 